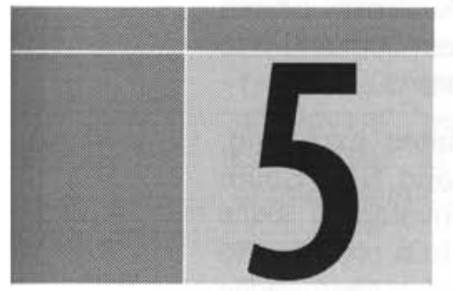

\title{
Cooperation in the Building Sector between Building- Material Manufacturers and Contractors to Develop Products
}

Jan Sundqvist, Bengt Larsson (University of Halmstad, Halmstad Sweden) and Göran Lindahl (Chalmers University of Technology, Gothenburg, Sweden)

\begin{abstract}
The Australian Construction Industry is now facing skills shortages in all trades. As an industry focused on the skill of its workforce, there is now concern the Australian standard in quality, workmanship, and productivity will inhibit both at national and international level.

This research paper addresses the underlying, influential factors concerning skills shortages in the Australian construction industry. The influential factors addressed include funding, training statistics, employer expectations, financial limitations, Industrial Relations and immigration. Given the reference to skills shortages within the industry, and documented in related literature, if skills shortages are to continue to exist, their effect will impact upon the overall performance of construction companies throughout Australia.
\end{abstract}

Keywords: Construction, Skills, Employment, Training, Labour, Industry

\section{INTRODUCTION}

The construction industry in Australia is currently undergoing revolutionary changes. Taylor (2004) draws attention to employment and skill retention, and outlines shortages are being influenced by the changes the economy has experienced and the unpredictable and erratic cyclical nature of the construction industry.

In 2003 the "Building and Construction Industry Improvement Bill" was drafted to amend some issues and implement some of the strategies found by the Cole Royal Commission national review of the conduct and practices in the building and construction industry in Australia (Royal Commissioner, 2003). When assessing the Cole Royal Commission Report, The Employment, Workplace Relations and Education References Committee (2004) found a "growing shortage of skilled labour".

Furthermore, Cole (1998) established from a report based on the future of the construction industry that evidence provided by building and engineering contractors shows concern of the declining levels of skills amongst site staff.

The Employment, Workplace Relations, and Education References Committee (2003) found that "the causes of skill shortages and skill gaps are often complex and multi-faceted with the specific causes varying with the industry and occupation". The National Industry Advisory Body (2003) identified a diverse range of factors contributing to current and future skill shortages. These include: an ageing workforce and forthcoming retirement rates; changing skills required from various occupations; differences in demand and/or supply of skilled workers as a result of employment arrangements; poor educational qualifications translating into smaller and lower numbers of successful job applicants; inadequate apprenticeship rates and difficulties in attracting and retaining employees (The Employment, Workplace Relations and Education References Committee, 2003).

Investigating issues similar to those expressed by The Employment, Workplace Relations and Education References Committee (2003), this paper is divided into correlating themes that relate to skills shortages in the construction industry. These themes have been highlighted in accordance with how they impact upon skills shortages; in addition the literature was studied to identify common trends and associated issues (Hampson and Brandon, 2004), together with relevant statistical data using historical and correlation methodologies. To conclude, a summary of the influential factors contributing to skills shortages is provided.

\section{OBJECTIVES}

The research question this paper aims to address concerns the underlying issues surrounding skills shortages in the Australian construction industry. The objective of the paper is to assess a collection of informed opinion on skill shortages and their causes in the Australian construction industry. The influential factors addressed include of funding, education and training, labour supply and demand, employer 
expectations and Industrial Relations and immigration on skills development. This paper reviews statistical data relating to the skills shortages to support the likelihood of future repercussions of skills shortages in the construction industry.

As there is little evidence on methods and/or procedures for alleviating skills shortages, the assessment of such techniques is outside the limits of this paper. In addition, the paper does not make direct reference to law, policies, or regulations, which may be associated with retirement or Industrial Relations and immigration.

The majority of the literature concerning skills shortages acknowledges its existence and outlines a cause. Yet, little is provided as future initiatives or methods of prevention. It is therefore important to assemble a collection of the underlying contributors influencing skills shortages so future solutions can be established, identified and implemented.

\section{FUNDING}

One of the common themes found within the literature concerns the funding crisis of training. The Employment, Workplace Relations and Education References Committee (2004) found "funding for training is a highly contentious element of the skills debate". Rance (2005) makes reference to government underspending on training and quoted Opposition Leader Kim Beazley to state, "The problem is that we have had chronic under-investment in education and skills training".

The funding of education and training is not a recent occurrence. Several authors discuss the historic pattern of a depleted level of investment in training and skills development. Toner, Green, Croce and Mills (2001) found that, between 1993 and 1996, the expenditure allocated by the Australian Government to training in the construction industry fell by $25.5 \%$. Ranch (2005) also stated that 1996 witnessed the first significant cuts made by the Australian Government to the national training and educational expenditure. These budget cuts entailed two $\$ 240$ million chunks from the vocational education and training budget and, for nine years, has had no increase. Furthermore, Cully (2002) found the "Commonwealth funding for the TAFE system remained fixed between 1997 and 2001, which has placed the system under considerable strain".

In addition to the Nation's annual budget being allocated to training, expenditure is distributed at state level, which, if desired, is available for education and training purposes. Many of the state governments within Australia have established training levy schemes dedicated to the building and construction industry.

Cully (2002) found that most states excluding, The Northern Territory, Victoria and New South Wales allocate a budget for developing skills amongst construction trainees. In a proposal to address the construction industries skills shortages the CFMEU (2005a) has produced a 10-point plan focusing on Apprentices. The CFMEU (2005a) indicates that one issue of concern is to "establish industry training funds in NSW, Victoria and the NT - in keeping with other states and territories".

Opposing literature, however, suggests that there has to be a level of financial commitment not only from government sectors but also from all stakeholders involved (Cully, 2002). It has been found that, to successfully operate within training markets, the costs and benefits of training need to be distributed between all those concerned (Toner, 2000). At present, some government subsidies exist for employers of apprentices/trainees. Toner (2003), however, found that "the incentive programme fails to strategically target scarce training funds on key skill shortages. The bulk of incentive funding is supporting traineeships in lower skilled occupations".

Currently, there is an increase in pressure from the Australian Government for private enterprise/employer funding of training (Pawle, 2004). The Royal Commission (2003) found that "a major weakness in the funding base for skills in contemporary Australia arises from the inadequate contribution to the training effort made by many employers. Many employers take skills for granted". Cole (1998) found that, because of the competitive nature of the building and construction industry, companies are now becoming smaller and more specialised. This trend of "specialised trades" is of concern as companies cannot implement all round adaptable skills and immobilise their provision to appropriate training programs (Cole, 1998). It is understood that the majority of construction firms in Australia are small companies and, as The Department of Industry, Tourism and Resources (2002) found, "less than 1 percent employ more than 50 people". Thus, many employers within the construction industry cannot afford to employ trainees if there is no incentive and no reassurance they will continue working for the company after their training is complete (Cully, 2002).The Employer and Group Training Company (1997) found that, from a survey conducted into apprenticeship employability, employers who undertook the survey expressed a need for an increase in employer subsidies or 
a reduction in apprentice wages, and a reduction or restructure in terms of off-the-job training. Taylor (2005) highlighted a need to understand employers' 'profit' in terms of the employees' capabilities to produce more than his or her employment costs.

Similarly, Cole (1998) found that, within construction sectors, there is "a need for apprentices working for these companies to be productive as soon as possible".

As the employer requires an apprentice to work for minimal pay, there is now conflicting issues arising from the wage of an apprentice in building trades. In the Northern Territory, the wage for a first year electrical apprentice is $\$ 5.40$ an hour, which The Employment, Workplace Relations and Education References Committee (2004) states, "is not a living wage". Similarly, the CFMEU (2005a) found skills shortages would improve if an increase in apprenticeship wages (especially for first year apprentices) and an introduction to adult apprenticeship wage rates was implemented. The CFMEU (2005b) states that, "skill shortages will only be overcome when government and employers start investing in the long term future of young Australians".

\section{DECREASE IN APPRENTICESHIP RATES}

As the primary form of education within the construction industry, apprenticeships promote the importance of trade learning through industrial experience, an attribute that has been found to place greater emphasis on the skills formation process (Harris and Simons, 2005). However there is currently an increase in the number of incomplete apprenticeships and an overall reduction in entrants into the apprenticeship program (Toner, 2003). The Master Builders Association of Australia (2006) found that "high drop out rate of building industry apprentices as they fail to complete their training, over the past ten years averaged around 50 percent, which translates into a loss of approximately 8,000 to 10,000 apprentices a year". Furthermore, The Australian National Training Authority "Australian Apprentice \& Trainee Statistics" showed that, between 1995 and 1998 there was a decline of 26,128 to 24,921 students/trades in training. Research also showed that, although 8,326 students started their training in 1995 , by 1998 only 6,045 of those students were completing their studies.

In 1996-1997 The Department of Employment, Education and Training and Youth Affairs (1998) found that apprenticeship approvals "were the lowest in 12 years". The CFMEU (2005a) found "with high rates of non-completion among apprentices, volatile training rates and an aging workforce, the Union argues that unless action is taken now, the industry will be plagued by skill shortages for many years to come".

The Employment, Workplace Relations and Education References Committee (2004) recognises a "cyclical pattern" amongst apprenticeship enrolments and, despite a moderate increase in the number of enrolments, the peaks and troughs of this cycle are now low compared to those of the last decade. In addition, Cole (1998) found "a fall in demand results in a fall in intake; thus the apprentice training patterns tend to follow short term cyclical demand for industry services, rather than the more desirable position of the development of long term skill base".

To resolve such issues, the government has created new training regimes that aim to provide basic or "soft skills" through short-course programs. The Employment, Workplace Relations and Education References Committee (2004) states that the industry must now decide "whether expenditure on training of low-level skills is justified in the absence of effective financial incentives for training at the high-end level of skills essential to the industry and construction". As the construction industry emphasises high levels of skill, its survival depends on longer duration training (as in the apprenticeship system) promoting the optimum output of qualifications.

In relation to the influence apprenticeships has on skills shortages within the construction industry The Employment, Workplace Relations and Education References Committee (2003) effectively summarise this and find that "the apprentice training rate will often need to increase in order to resolve the skill shortage and meet new training needs associated with employment growth and to replace retirements and attrition".

\section{INCREASE IN AGED POPULATION}

Demographic trends are highlighting escalating retirement rates in the construction sector (The Employment, Workplace Relations and Education References Committee, 2004). The Australian workforce is retiring earlier than workers in comparable countries. Parker (2004) found that "in Australia, only $49 \%$ of people between the ages of 55 and 64 are in the workforce, compared to $59 \%$ in the US". In 2004 the Australian Government allocated \$12 million towards a campaign designed to encourage mature-aged Australians to stay in the workforce. Parker (2004) states that employers need to show understanding in terms of "the benefits that older workers provide, both 
in terms of accrued expertise and through their alignment with an ageing community and customers".

A review of the literature surrounding ageing populations illustrates the need for an increase in apprenticeship numbers to replace retirees. Furthermore, retention of mature staff members, should been seen as a valuable source for "soft skills" in which new entrants to the industry may take a lifetime to learn. Moreover, The Employment, Workplace Relations and Education References Committee (2004) found "the looming critical skills shortage needs to be seen in the context of expected high levels of construction over the period to 2007 and the effects of retirements from the industry".
Using samples from the Australian Bureau of Statistics (ABS), the employment characteristics of transitions from education into the construction industry can be established. Using data from the ABS "Labour Force" statistics, a graph has been developed to represent the percentages of employed persons in the construction industry in terms of age group. See Table 1

Table 1 illustrates a cycle in terms of new entrants into the construction industry. Age group 15-19 only accounts for $6 \%$ of the total persons in the industry, whereas age group 4554 (workers who may be considering retirement) represent $19 \%$. It is thus critical to predict supply and demand in order that the skills supply to the future of the industry is maintained.

Employed Persons in the Construction Industry (\%)

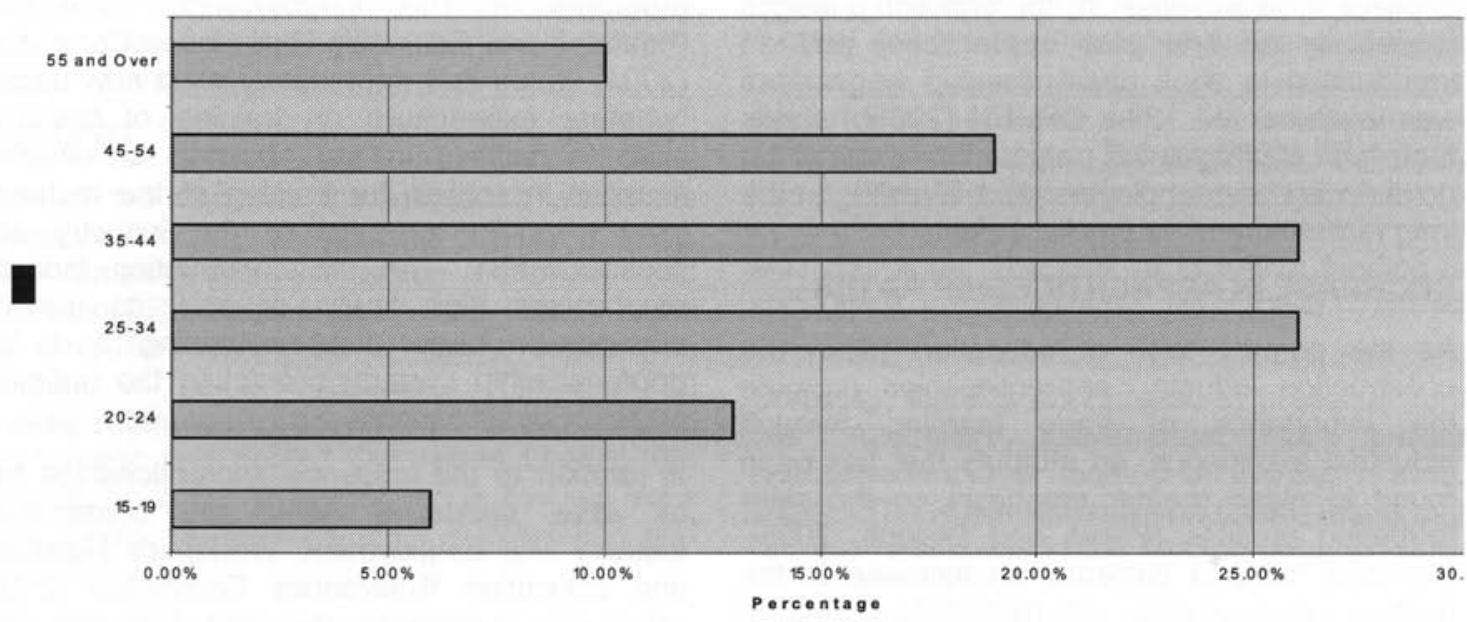

Table 1 Employed Persons in the Construction industry as a Percentage

\section{SUPPLY AND DEMAND}

The Employment, Education and Training Affairs Youth (1998) conducted a survey from 19971998 into the 'demand' for people to fill skilled vacancies in the construction industry. From the data, it is found that the construction industry comprises $19 \%$ of the total skilled vacancies that exist in Australia. The Master Builder Association of Australia (2006) estimates that " 80,000 skilled building workers will exit the industry by 2010 to be replaced by only 40,000 new apprentices who will have completed their trade courses, leaving a shortfall of 40,000 skilled tradespeople".

The Department of Employment, Education, Training and Youth Affairs (1998) concluded from this that one of the factors influencing skills shortages relates to insufficient manpower prediction. "Manpower" has been traditionally used to predict and represent the forecasted supply and demand of labour. When referring to the importance of manpower prediction Wong, Chan and Chiang (2004) identified that "imbalances between the demand for and supply of specific skills in the construction industry is particularly important since it contains a large number of distinct skill categories".

A historical comparison of supply and demand can be made through the "Occupational Outlook, 1986". The previous Department of Employment and Industrial Relations Occupational Analysis Branch (1987) found that, within construction sectors, very few completions of formal training were made, limiting provision to the supply of the labour. In addition, The Department of Employment and Industrial Relations Occupational Analysis Branch (1987) 
acknowledged that levels of activity influence the demand required and indicated "replacement demand is stable at 1-2 per cent per annum". As a comparison to these figures The Australian National Training Authority (2002) recorded that, for every 8-employment vacancy available, eight people were employed. Both percentages from 1986 and 2002 indicate that levels of supply and demand are equivalent, contrary to previously establish data stating otherwise.

Typical supply and demand trends within the construction industry are cyclic in nature, consisting of short-term levels of construction performance and an increase in demand for construction services, resulting in a rise in apprentice intake (Cole, 1998). Toner (2000) found this to be partially influenced by the industry's high level of self-employment and temporary employment.

Low levels of permanent employment result in high levels of "turn-over", leading to a low-level return on investment in training. As a result skilled labour becomes high in demand (The Employment, Workplace Relations and Education References Committee, 2004). The Department of Employment, Education and Training and Youth Affairs (1998) found that a "combination of continued growth in demand and low supply from apprenticeship completions indicates that more widespread shortages in building trades may develop".

\section{TRAINING}

The Employment, Workplace Relations and Education References Committee (2004) draws attention to low levels of qualifications in the industry and states that "only $\mathbf{4 5}$ per cent of the workforce" has formal qualifications and "29 percent of employers in the industry provide structured training". Assessing the training packages available, the Master Builders Association of Australia (2006) have found the "training system is struggling to keep up with the new demands of the building industry in response to changing building technologies and construction techniques particularly in the highly competitive residential 'suilding sector".

Hampson and Brandon from The Cooperative Research Centre for Construction Innovation (2004) developed a booklet that captured the views of those currently working in the Australian construction industry on the future innovations for the year 2020. Results of this study highlighted skills and education as high priorities, and expressed concerns that skills are not adequately being developed to ensure the future of the industry (Hampson and Brandon, 2004).
The Housing Industry of Australia (2006) found that "unless reforms are enacted to make training more attractive and accessible, the industry will face a growing shortage of skilled workers".

Previously, students gaining qualifications through TAFE (Technical and Further Education) comprised 95 per cent of all apprenticeships in the construction industry (Toner, 2005). Today, there is a wide variety of training programs available, which vary in terms of course delivery and flexibility. The traditional form of training, the apprenticeship, is under pressure to deliver the qualities that are exhibited by some of the more current forms of training. The Employment Workplace Relations and Education References Committee (2004) found that the apprenticeship system is built on "trade skills training" and that there is uncertainty as to whether such a method of skill development "is sufficiently enterprise focused and sufficiently specialised".

It has been found that, for the apprenticeship system to continue, close attention must be paid to ensure that apprentices are offered the range of skills and knowledge that a trade or profession of modern practice requires (Toner, 2003).

In addition, the outcomes of all stakeholders involved need to be clearly defined and justified, as Toner (2005) found that teachers in TAFE education can show "self-interest in supporting traditional training as the continuity of their jobs depends on funding for longer duration training". The Employment, Workplace Relations and Education References Committee, (2004) found that resentment has been witnessed on the behalf of builders and contractors towards TAFE components of an apprenticeship. It is argued that TAFE dedicates too much time and places too much importance on theory at the expense of practical experience (The Employment, Workplace Relations and Education References Committee, 2004).

Correlations are found in the literature in terms of whether training packages are sufficient in meeting industry demand (Buchanan and Sullivan, 1996). Cole (1998) found that, in terms of skills development, the main area of concern include: training in interpersonal skills in marketing, negotiating and communicating with clients and others involved, training in building processes and building materials, training in the management and operation of small plant and site communication equipment, and training in occupational health and safety issues.

It is necessary for Australia to continue to reexamine training and skill development packages to meet current industry demand. 
Toner (2005) found that continually revising "training packages over the last decade have led to a more nationally consistent content in training delivery". An example of one such upgrade to training package is school based vocational education and training. This is an aspect that most found necessary to accommodate for the latest skill requirements needed for both the construction industry and the requirements of employers (Stromback, 1996). To address the key areas of concern within the training packages available, the Housing Industry of Australia (2006), found there is a need to:

- Encourage a flexible course delivery and choice in training courses

- Attract young people to trades training

- Reverse the high rate of drop-out from training

- Address the cost to small business employers when employing apprentices

- Reform Industrial Relations restrictions preventing more relevant and timely training

\begin{tabular}{|c|c|c|c|c|c|c|c|}
\hline Year & $\begin{array}{l}\text { Higher } \\
\text { Degree } \\
\text { '000 }\end{array}$ & $\begin{array}{l}\text { Postgraduate } \\
\text { Degree } \\
' 000\end{array}$ & $\begin{array}{l}\text { Bachelor } \\
\text { Degree } \\
' 000\end{array}$ & $\begin{array}{l}\text { Under- } \\
\text { graduate } \\
\text { Diploma } \\
' 000\end{array}$ & $\begin{array}{l}\text { Associate } \\
\text { Diploma } \\
\text { ‘000 }\end{array}$ & $\begin{array}{l}\text { Skill } \\
\text { Vocational } \\
\text { Qualification } \\
\text { '000 }\end{array}$ & $\begin{array}{l}\text { Basic } \\
\text { Vocational } \\
\text { Qualification } \\
\text { '000 }\end{array}$ \\
\hline 1996 & 3.4 & 1.2 & 21.7 & 6.0 & 43.9 & 276.5 & 23.7 \\
\hline 1998 & 2.8 & 2.6 & 21.2 & 14.8 & 16.1 & 240.7 & 43.7 \\
\hline 2000 & 2.7 & 3.2 & 27.6 & 16.2 & 22.4 & 263.7 & 50.9 \\
\hline
\end{tabular}

Table 2 (Australian Bureau of Statistics, pg. 14, 22, 1996, 1998, 2000)

From the data shown in Table 2 there is a significant difference between the levels of qualification, individuals working in the construction industry possess. As outlined, a continuing trend of VET or apprenticeship qualifications is seen within the industry. In addition, there is an increasing pattern of lowlevel educational qualifications within the industry and, as previously addressed, a trait that an industry experiencing skills shortages should abstain from.

From a study conducted by the Employer and Group Training Company (1997) on the assessment of apprentices' skills and qualifications on recruitment, out of 515 applicants assessed from the construction industry, only $20 \%$ were suitable for employment. In addition, the study showed that, on employment, positions were originally filled but
From a review of the annual report into the Australian Vocational Education and Training System, 2002, levels of competency were measured over a four-year training package (The Australian National Training Authority, 2002). It was shown that, in the initial stages of training, competency units were measured at 4,359 units and, in the final year of training, at 128,265 units. Ultimately these figures draw attention to poor levels of trainees' education and/or skills in their first year of study. However, in the second year of training, students are found to have 41,446 units of competency, which is an increase of close to ten times the initial level displayed by students in their first year.

To give an indication of the qualifications that exist in the construction industry, the following data collected from the Australian Bureau of Statistics has been tabulated. Table 2 represents the qualifications of people working full time in the industry over a five-year period starting from 1996. See Table 2 (ABS, 1996, 1998, 2000): the apprentices had either left soon after recruitment or employers were not satisfied and had discharged them during their probationary period (The Employer and Group Training Company, 1997).

Opposing literature, however, states that employers are finding apprenticeship skills and knowledge to be of satisfactory levels (The Australian National Training Authority, 2002).

Toner (2005) showed that "it is also important to note that surveys of employers reveal a high level of satisfaction with the quality of TAFE training". From a survey of views from employers within the construction industry on the VET system (2002) it was found that the median satisfaction rating was 6.97 . 
INDUSTRIAL RELATIONS, IMMIGRATION \& MIGRATION

Another concern The Employment, Workplace Relations and Education References Committee (2004) expressed when reviewing the report from the Royal Cole Commission was the Australian Government's changes to the construction industry Industrial Relation (IR) regimes. The recent amendments the government made to install "order and discipline" to the IR policy has been predicted to result in the opposite effect of what was intended (Employment, Workplace Relations and Education References Committee, 2004). Calver (2005) found that, in general, the outcome of IR amendments was "further streamlining of industrial awards, with anticipated changes to the National Building and Construction Industry Award". This change to the wage structure is intended to produce cheap labour. However, the overall cost to employ labour will rise as there is an overall national skills shortage (Employment, Workplace Relations and Education References Committee, 2004). Sutton (2006) from the CFMEU stated that "Wages in the commercial construction industry have increased by approximately $60 \%$ over the last 10 years". Buchanan and Sullivan (1996) also acknowledge this issue, and find "wage pressure arising from skill shortages in construction will be detrimental to the economy in general and owners in particular".

Due to decreases in the supply of skilled labour and rises in the cost of skilled labour the Australian Government deregulated the law regarding temporary entry work visas in 1996, resulting in skilled overseas workers currently in temporary employment opportunities in Australia (Birrell et al, 2004). Although this is so, Toner (2001) found that "migration has a neutral effect on overall employment growth, in that migrants create as many jobs as they take".

Giving further consideration to skills migration and immigration, Toner (2001) highlighted the difference in qualifications and percentages of immigrants and Australian residents in the workforce, employing data from 1981-1999. Using these data, two tables have been established that compare the qualifications of immigrants and Australian residents and illustrate the percentages of those in the workforce. See Table 3 and 4

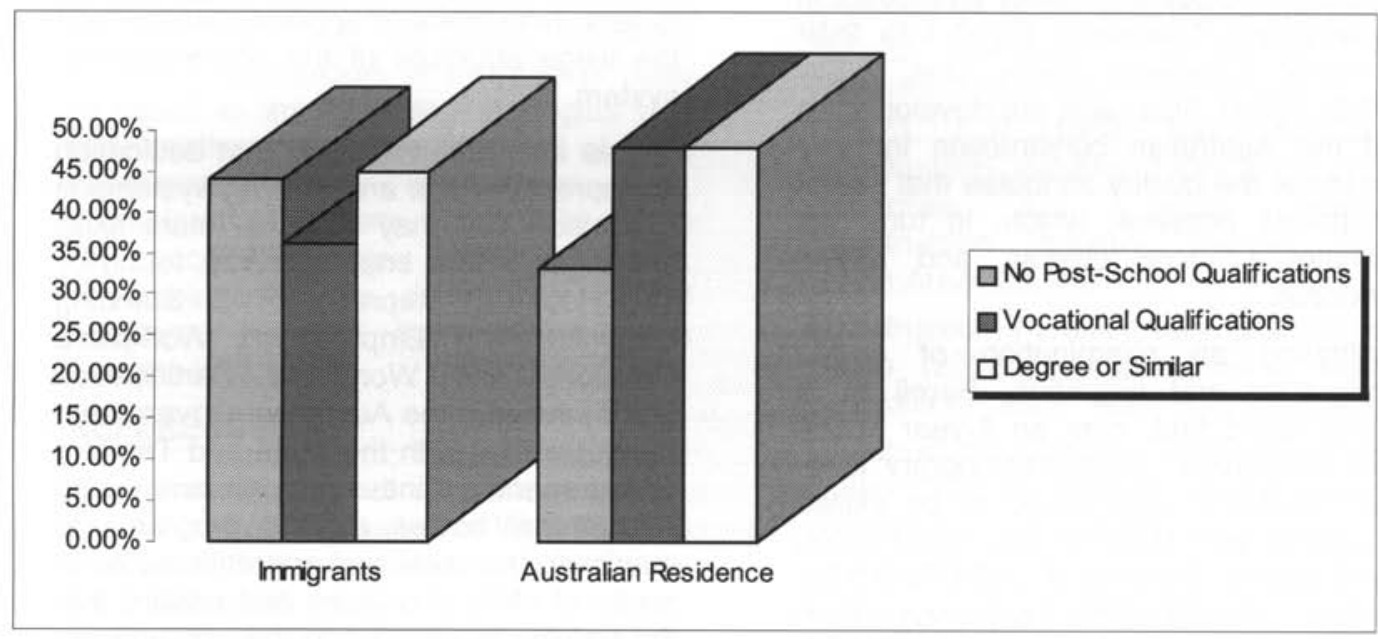

Table 3 Qualifications of Immigrants and Australian Residents (total \%)

\begin{tabular}{|l|l|l|l|}
\hline & Construction & $\begin{array}{l}\text { Electrical, Gas and } \\
\text { Water Supply }\end{array}$ & $\begin{array}{l}\text { All Other } \\
\text { Industries }\end{array}$ \\
\hline $\begin{array}{l}\text { Immigrants: } \\
\text { Non-English Speaking Background }\end{array}$ & 6.80 & 0.60 & 92.60 \\
\hline $\begin{array}{l}\text { Immigrants: } \\
\text { English Speaking Background }\end{array}$ & 7.50 & 0.60 & 91.90 \\
\hline Australian Residence & 7.30 & 0.70 & 92.00 \\
\hline
\end{tabular}

Table 4 Percentages of Immigrants and Australian Residents in the Workforce 
Table 3 illustrates a substantial percentage of highly educated/skilled immigrants in the Australian workforce. However, there are also similar percentages of immigrants who possess low-level education/skill, causing concern for the approval of these unskilled immigrants, as Australia continues to maintain skills shortages. Table 4 shows that a major percentage of the construction industry is comprised of immigrants.

The most common forms of migration into Australia are currently SkilledIndependent and Skilled-AustralianSponsored. Two of the key problems faced by these immigrants include their lack of understanding of employment procedures in Australia and their little or no grasp of the English language (Pawle, 2004). In response to these issues, The National Office of Overseas Skills Recognition (NOOSR, 2004) was implemented. NOOSR outlined their "mission is to help the overseas trained to work and study in Australia". Furthermore, various states and territories have introduced booklets to assist employers in implementing "overseas skills" into their company (Overseas Skills Unit, NSW AMES, 2004). Such aids are developed so that the Australian construction industry can utilise the quality attributes that skilled immigrants possess, which, in turn, will promote a more diverse and skilled workforce.

Continuing an examination of skilled immigration and migration, Birrell et al (2004) found that, over an 8-year period from 1995-2003, 36,259 temporary longterm residents were found to be skilled occupants with building and construction qualifications. Birrell et al (2004) found the number of residents departing from Australia over an 8-year period (19952003) in the construction sector were 32,634 building professionals and 11,911 tradespersons. Birrell et al (2004) found that "a substantial loss of skilled Australian residents, particularly those with professional occupations, naturally causes concern because it means there is a departure of people who have been trained at the Australian community's expense".

Immigration as a solution to skills shortages is still under debate to whether or not it is having anything more than a "neutral" effect. The CFMEU (2005b) believe that "rather than bringing in cheap labour from overseas, the Howard
Government needs to look at improving pay and conditions, and rewarding good employers who put effort into training local apprentices".

\section{CONCLUSIONS FOR THE FUTURE}

The Australian construction industry relies heavily on the skills of its workforce to be productive at both national level and international level. Hampson and Brandon (2004) found "as construction is highly labour intensive, one goal for 2020 is for an ongoing supply of skilled workers to service this vital Australian industry".

When revising the literature review, it has become evident that there are several trends and interrelated issues that are impacting upon the skills shortages faced by the construction industry. In relation to funding contributions made to training and skill development, some common themes where highlighted. These include: an historic pattern of low-level investment to education and training made by both the Australian national and state governments, a need for there to be joint contributions made on behalf of all stakeholders involved, construction downsizing resulting in less investment in apprenticeships, and the wage structure of the apprenticeship system.

It was also recommended that dedication to apprenticeships and training systems is a solution that may improve future skills shortages. Such improvements, found by The House of Representatives Standing Committee on Employment, Workplace Relations and Workforce Participation (2005) include "the Australian Government in cooperation with the State and Territory Governments, industry, unions and educational bodies expand programs to maximise the uptake of apprenticeships in areas of skills shortages and ensure that the training is relevant to the apprentices, the businesses and the industry".

When reviewing the correlation between an ageing population and skills shortages, attention was drawn to the high demographic trends of early retirement seen within the construction industry. Concern was established, as an inadequate percentage of people are entering the industry, which do not accommodate for retirement losses. It has therefore been recommended that ageing members of the workforce be seen as valuable assets and are employed for longer durations.

As previously stated, the levels of supply and demand are imbalanced. It was found, 
that in order to ensure these percentages improve, there must be a greater emphasis placed on education and training. When assessing the influence of training on skills shortages, it was found that a culture of scrutinising has promoted the adaptive skills required by the demand of a modern society. Furthermore, with a history of success and appropriate modifications, the apprenticeship system, is still a valuable source of training for a new entrant to the construction industry.

To summarise the impact Industrial Relations has on skills shortages, it was found, that concerns were expressed over changes to wage structure. Deregulation of the Award and wage determinants is predicted to substantially increase the cost of future labour as a result of skills shortages. In terms of immigration as a solution to skills shortages, it was found that the percentage of immigrants needed to fill skilled vacancies is equal to the percentage of vacancies immigration produces.

For the construction industry of Australia to be promoted as innovative and productive in terms of supplying resources and raising levels of gross domestic product, stakeholders at every level need to assist in implementing strategies and preventatives to reduce the level of skills shortages. As The Employment, Workplace Relations and Education References Committee (2004) concluded, "if training fails to deliver the skilled workforce required then other issues become irrelevant".

\section{REFERENCES}

Australian Bureau of Statistics, (1996). Transition from Education to Work. 6227.0. Australian Bureau of Statistics, Canberra, ACT, Australia.

Australian Bureau of Statistics, (1998). Transition from Education to Work. 6227.0 Australian Bureau of Statistics. Canberra, ACT, Australia.

Australian Bureau of Statistics, (2000). Transition from Education to Work. 6227.0. Australian Bureau of Statistics. Canberra, ACT, Australia.

Australian Bureau of Statistics, (2003). Australian Labour Force. 6203.0. Australian Bureau of Statistics. Canberra, ACT, Australia.

Australian National Training Authority, (2002). "Annual National Report of the Australian Vocational Education and Training System 2002." Report on the Key Performance Measures for the Australian
Vocational Education and Training System 3.

Bennington, L. and Tharenou, P. (1996). "Older Workers: Myths, Evidence and Implications for Australian Managers." Asia Pacific Journal of Human Resources 3(34): 13.

Birrell. B, Dobson. I.R, Rapson. V, and Smith. T.F, (2004). "Skilled Movement in The New Century: Outcomes for Australia. Department of Immigration and Multicultural and Indigenous Affairs. Canberra, ACT, Australia, Centre for Population and Urban Research, Monash University: 103.

Buchanan. J, and Sullivan, G. (1996). Skills Formation in the Construction Industry - Lessons from some Recent Innovations. Working Paper No. 45. Australian Centre for Industrial Relations Research and Training. Sydney, University of Sydney: 28.

Calver, R. (2005). Building and Construction Workplace Relations Reform. Newcastle, Australia, National Director Industrial Relations, and Legal Counsel.

Clabuagh, C. A., Ed. (1998). The Implications of Downsizing. Managing an Ageing Workforce. Warriewood, NSW Australia, Woodslane Pty Ltd.

Cole. L. J. R, (1998). The Future of the Construction Industry 1998-2010. JEASA Nominees Ltd. South Australia, Construction Industry Training Board, South Australia. 44.

Construction, Forestry, Mining and Energy Union (2005a). "Apprentices - building Australia's Future." Hard Hat(Nov/Dec): 1.

Construction, Forestry, Mining and Energy Union, (2005b). "Protest Against Importing Apprentices." Hard Hat(Nov/Dec): 1.

Construction, Forestry, Mining, and Energy Union, (2006). "Priority Issues for Workforce Skills Development". Construction and Property Services Industry Skills Councils conference, Sydney, NSW, Australia.

Construction and Property Services Industry Skills Councils (2005). Draft Industry Skills Report. Department of Education, Science and Training. Canberra, ACT, Australia: 95.

Cooper, D. (2004). Improving People Performance in Construction. Aldershot, England, Gower Publishing Group.

Crock, M. Saul, B. (2002). Nation Skilling: Immigration, Labour and The Law. Sydney, Desert Pea Press. 


\section{INSTRUCTIONS/GUIDELINES FOR AUTHORS TO THE AUSTRALASIAN JOURNAL OF CONSTRUCTION ECONOMICS AND BUILDING}

\section{Submission}

Two issues (June and December) per annual volume of the journal are planned. Authors are requested to submit papers for publication at any time to:

Robyne Nash, Education Officer, Australian Institute of Quantity Surveyors

Postal address: PO Box 301, Deakin ACT 2600, AUSTRALIA

Email: education@aiqs.com.au

Phone: 61262822222

Papers will be referred to acknowledged experts for comment as to suitability, originality, interest and content. Only those receiving favourable recommendations from the referees will be accepted for publication. If an author is uncertain about whether a paper is suitable for publication, it is acceptable to submit a synopsis first.

\section{Submission of Disks}

Disks must be supplied with the manuscript. Contributors should submit a 3.5 disk formatted on a PC or Macintosh computer in MS Word (version 5 and above) and/or Excel (version 4 and above) or email their papers to the above address. Papers in Word format is the most acceptable.

\section{Effective Communication}

The paper should be written and arranged in a style that is succinct and easily followed. An informative title, a concise abstract and a well-written introduction will help to achieve this. Simple language, short sentences and a good use of headings all help to communicate information more effectively. Discursive treatments of the subject matter are discouraged. Figures should be used to aid the clarity of the paper, not pad it out. Think about your reader.

\section{English Language Assistance}

As the language of the publication is English, it is strongly recommended that non-English speaking authors seek assistance from a competent English writer to ensure the spelling, grammar and style is correct. The Editor may be able to assist in identifying appropriate people to consult.

\section{Manuscript}

\section{(a) Presentation}

Depending on their nature, papers may be up to 5,000 words in length. Manuscripts should be typed 1.5 spacing, left hand justified, including references. A brief autobiographical note should be supplied including full name, position held and name of employing organisation. The manuscript should be arranged under headings and subheadings.

\section{(b) Title page}

The first page of the manuscript must contain the full title, the affiliation and address of the author(s), a running title of not more than 75 characters and spaces, the name and address of the author who will be responsible for correspondence and correcting the proofs, and up to five keywords for the purposes of indexing.

\section{(c) Keywords}

Authors should also provide 5 keywords or descriptors that clearly describe the subject matter of the article. These terms have two purposes: to help describe the subject content of an article to prospective readers; to index the article for retrieval from a database or bibliography. Such keywords might include: Country, geographical area, e.g. New Zealand, Micronesia; Organisation/ organisation related, e.g. Building Industry, Public Works; People, e.g. consultants, quantity surveyors, sub-contractors; Specific processes, technologies or applications, e.g. databases, TQM, advanced manufacturing technology; Broad functions or disciplines, e.g. information technology, cost management, innovation studies; Other processes and subject areas, e.g. industrial relations, economics, design, research

\section{(d) The abstract}

An abstract should be included. It must not exceed 200 words and must precis the paper giving a clear indication of the conclusions it contains.

\section{(e) Illustrations}

Illustrations must accompany the manuscript but should not be included in the text. Photographs, standard forms and charts should be referred to as 'Fig. 1', 'Fig. 2' etc. They should be numbered in the order in which they are referred to in the text. Indicate where in the text you wish the figure to appear. Send accurate and clear drawings to enable good reproduction.

Tables should be numbered consecutively and independently of any figures. Each table must have a number, a brief title, and headings down and 
across. Type tables on separate sheets of paper, and indicate in the text where you wish them to appear.

Photographs, preferably transparencies, should be labelled with the figure number and an indication of which is top. Where lettering is to appear on the photograph, two prints should be supplied, one of which should be left unlettered.

\section{(f) Measurements}

Metric units should be used; if other units are used then metric equivalents should be given in parentheses.

\section{(g) References}

The Harvard system is used. References in the text should be quoted in the following manner: Smith (1975 ) ... or ... Brown and Green, (1976) ... or, if there are more than two authors ... Jones et al. (1980). References should be collected at the end of the paper in alphabetical order by the first author's surname. If references to the same author have the same year, they should be differentiated by using $1980 \mathrm{a}$ and $1980 \mathrm{~b}$ etc. The style should follow the examples below:

Smithers, N. (1966). Cost benefit analysis in town planning. Urban Studies, 33, 4-27.

Stone, P. A. (1980). Building Design Evaluation: Costs-In-Use. E. \& F.N. Spon, London.

Burnes, S. (1981). Implementation of public policy. In Policy and Action (edited by S. Barrett and C. Fudge), pp. 1-33. Chapman and Hall, London.

If no person is named as the author the name of the organisation should be used, for example:

Australian Institute of Quantity Surveyors (1980) Report on Quantity Surveying Methods, Canberra.

(h) Notes

A limited number of explanatory endnotes is permissible. These should be numbered 1, 2, 3, consecutively in the text and denoted by superscripts. They should be typed on a separate sheet of paper at the end of the text. Endnotes should not be used for academic or project citations.

\section{Proofs}

Proofs will be sent to the corresponding author for correction. The difficulty and expense involved in making amendments at proof stage make it essential for authors to prepare their manuscript carefully: any alterations to the original text are strongly discouraged. Our aim is rapid publication: this will be helped if authors provide good copy following the above instructions, and return their proofs as quickly as possible. The editors reserve the right to amend style, grammar and typographical errors without reference to the authors.

\section{Copyright}

Submission of an article to THE AUSTRALIAN JOURNAL OF CONSTRUCTION ECONOMICS AND BUILDING is taken to imply that it represents original, unpublished work, not under consideration for publication elsewhere. Authors submitting articles for publication warrant that the work is not an infringement of any existing copyright and will indemnify the publisher against any breach of such warranty.

On submitting a manuscript, authors will be asked to transfer the copyright for their article to the Publisher if and when the article is accepted for publication. The copyright covers the exclusive rights to reproduce and distribute the article, including reprints, photographic reproductions, microfilm or any reproduction of a similar nature, and translations.

Permission to publish illustrations must be obtained by the author before submission and any acknowledgments should be included in the figure captions.

\section{Refereeing Procedure}

The decision whether or not to publish is the Editorial Board's. At least two members of the Editorial Board, and/or other acknowledged experts will be consulted. 

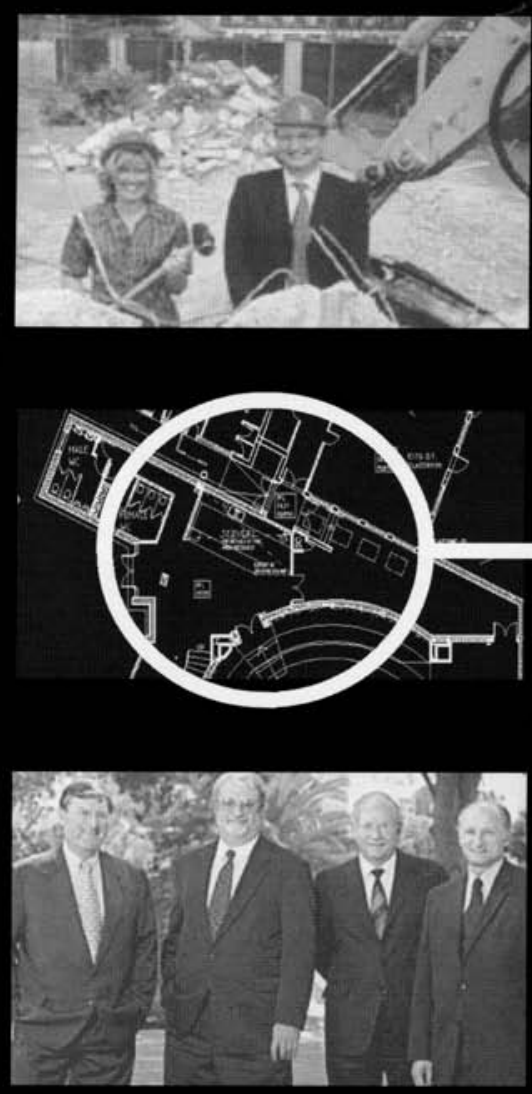

\section{CONSTRUCT 2008}

The Conference For Building Professionals 21-23 February 2008 - Gold Coast, Australia

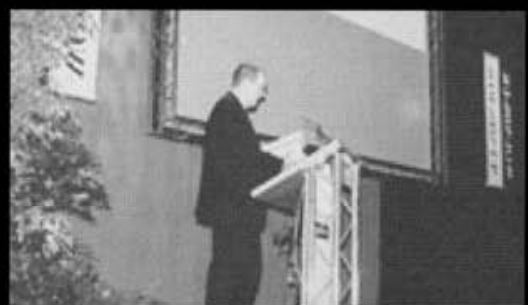

Building on the success of last year's conference, the Australian Institute of Building (AIB) is pleased to announce CONSTRUCT 2008.

Over two and a half days CONSTRUCT 2008 will address the key issues relevant to all professional builders and other stakeholders with an interest in the management of a building project or construction firm. Dedicated sessions address:

IIIII Building codes compliance and certification issues

IIIII Compliance documentation and regulatory developments

IIIII Public sector project delivery

IIIII Green construction techniques

IIIII Building site safety issues

IIIII Case studies

The program includes industry leaders, senior government officials and academics in building and construction disciplines. For information on the program visit the CONSTRUCT 2008 website at:

\section{www.construct.org.au}

With a focus on improving the effectiveness of individuals within the building profession, CONSTRUCT 2008 enables delegates to share experiences and form professional networks to strengthen the building profession and its contribution to society.

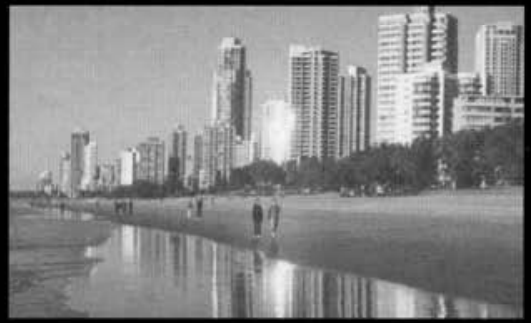

The conference is all about assisting building professionals develop a better understanding of the commercial, technical and regulatory environment in which they work. This knowledge will allow those attending CONSTRUCT 2008 to be better managers and mentors to the next generation of building professionals.

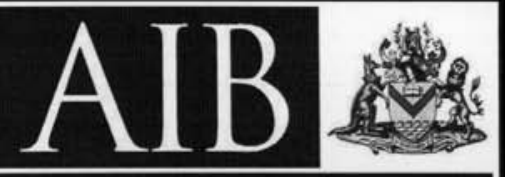

The Australian Institute of Building

- Incorporated by Royal Charter 


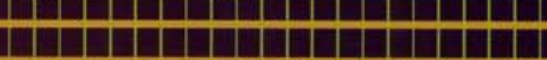
(1)

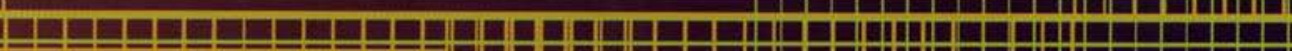
$\mu_{2}$

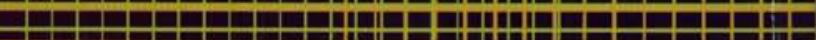
- In

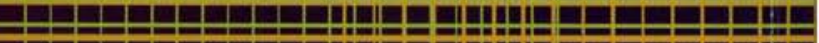

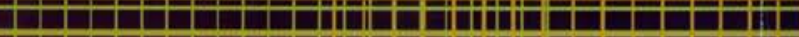

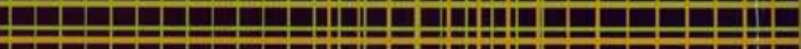
12 12 2 20

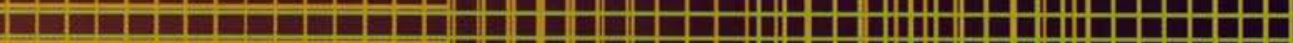
5 -

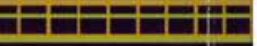

और

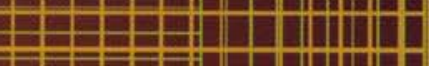

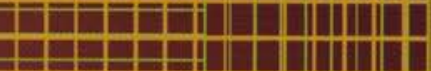

2 -

$+2$

H

- 1 -

II 1 ||

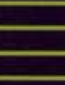

$+2$
$+2$

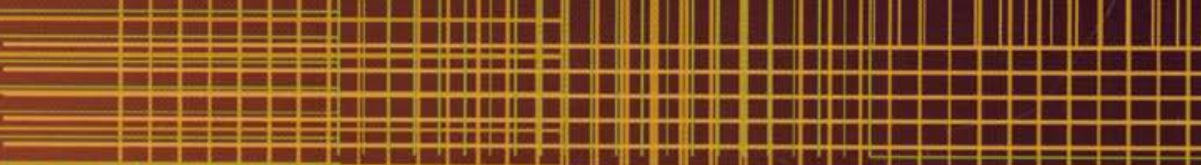

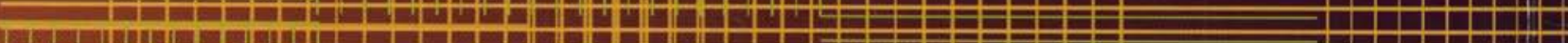

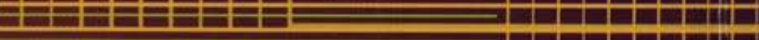
H In

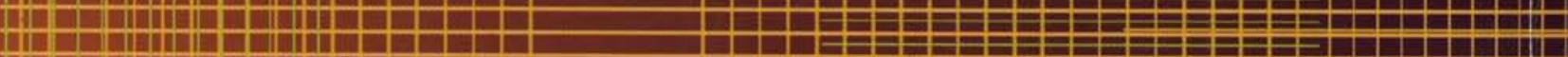

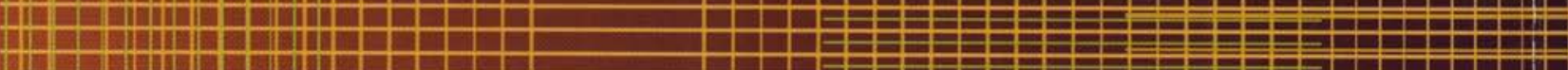
HAIQS IH THE AUSTRALIAN INSTITUTE OF BUILDING
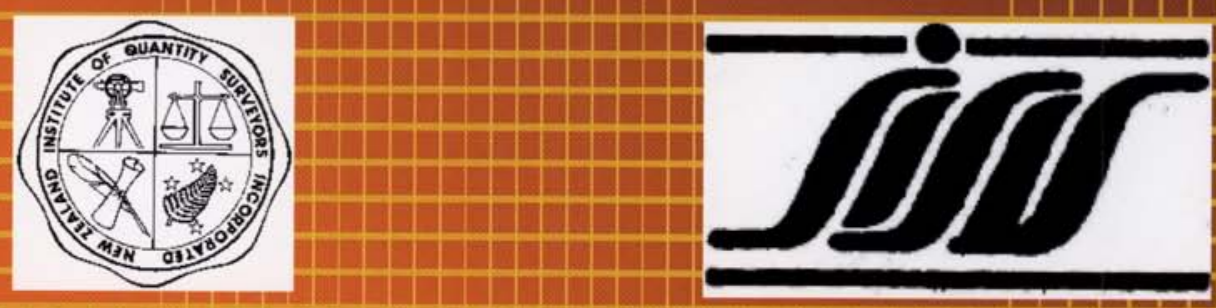

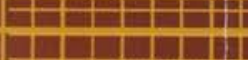

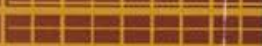

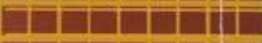

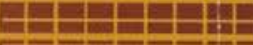

